\title{
ERo expression in T lymphocytes is dispensable for estrogenic effects in bone
}

\author{
K L Gustafsson', K H Nilsson', H H Farman', A Andersson', V Lionikaite', P Henning', J Wu', S H Windahl', \\ U Islander ${ }^{2}$, S Movérare-Skrtic ${ }^{1}, \mathrm{~K}$ Sjögren ${ }^{1}$, H Carlsten $^{2}$, J-Å Gustafsson ${ }^{3}, \mathrm{C}$ Ohlsson ${ }^{1}$ and M K Lagerquist ${ }^{1}$ \\ ${ }^{1}$ Center for Bone and Arthritis Research, Department of Internal Medicine and Clinical Nutrition, Institute of Medicine, Sahlgrenska Academy, University \\ of Gothenburg, Gothenburg, Sweden \\ ${ }^{2}$ Center for Bone and Arthritis Research, Department of Rheumatology and Inflammation Research, Institute of Medicine, Sahlgrenska Academy, \\ University of Gothenburg, Gothenburg, Sweden \\ ${ }^{3}$ Center for Nuclear Receptors and Cell Signaling, Department of Biology and Biochemistry, University of Houston, Houston, Texas, USA
}

Correspondence should be addressed to M K Lagerquist: marie.lagerquist@gu.se

\section{Abstract}

Estrogen treatment has positive effects on the skeleton, and we have shown that estrogen receptor alpha $(E R \alpha)$ expression in cells of hematopoietic origin contributes to a normal estrogen treatment response in bone tissue. T lymphocytes are implicated in the estrogenic regulation of bone mass, but it is not known whether $\mathrm{T}$ lymphocytes are direct estrogen target cells. Therefore, the aim of this study was to determine the importance of ER $\alpha$ expression in T lymphocytes for the estrogenic regulation of the skeleton using female mice lacking $E R \alpha$ expression specifically in T lymphocytes

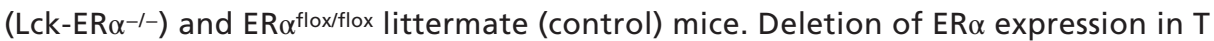
lymphocytes did not affect bone mineral density (BMD) in sham-operated Lck-ER $\alpha^{-l-}$ compared to control mice, and ovariectomy (ovx) resulted in a similar decrease in BMD in control and Lck-ER $\alpha^{-/-}$mice compared to sham-operated mice. Furthermore, estrogen treatment of ovx Lck-ER $\alpha^{-l-}$ led to an increased BMD that was indistinguishable from the increase seen after estrogen treatment of ovx control mice. Detailed analysis of both the appendicular (femur) and axial (vertebrae) skeleton showed that both trabecular and cortical bone parameters responded to a similar extent regardless of the presence of $E R \alpha$ in T lymphocytes. In conclusion, ER $\alpha$ expression in T lymphocytes is dispensable for normal estrogenic regulation of bone mass in female mice.

\section{Key Words}

- Tlymphocytes

- estrogen receptor alpha

- estrogen

- bone loss

\section{Introduction}

Estrogen, the main female reproductive hormone, is a major regulator of bone homeostasis and it is well known that estrogen deficiency after menopause increases fracture risk and that estrogen treatment decreases this risk (Ettinger 1988). However, estrogen is not suitable as treatment due to severe side effects such as increased risk of cancer in reproductive organs and venous thrombosis (Rossouw et al. 2002, Barrett-Connor et al. 2005, Khosla 2010, Marjoribanks et al. 2017). It is therefore important to identify the mechanisms behind the skeletal effects of estrogen to be able to separate the positive bone protective effects from the negative side effects in order to facilitate development of new tissue specific treatments. The effects of estrogen are mediated primarily via the estrogen receptors (ERs), ER alpha (ER $\alpha)$ and ER beta (ER $\beta)$, and ER $\alpha$ is considered the main regulator of the protective effects of estrogen in the skeleton (Lindberg et al. 2002, Walker $\&$ Korach 2004). ER $\alpha$ is expressed in several cell types of 
mesenchymal origin, including bone forming osteoblasts and osteocytes, and an important role of ER $\alpha$ expression in these cell types for the skeleton has recently been demonstrated (Windahl et al. 1999, Almeida et al. 2013, Maatta et al. 2013, Melville et al. 2014). Furthermore, ER $\alpha$ expression in osteoclasts, originating from hematopoietic stem cells, has also been shown to affect the skeleton (Nakamura et al. 2007, Martin-Millan et al. 2010). Our group has demonstrated that ER $\alpha$ expression in hematopoietic cells is important for a normal estrogen treatment response in bone (Henning et al. 2014) and other cells of hematopoietic origin, aside from osteoclasts, have been shown to be involved in the estrogenic regulation of bone mass, including $\mathrm{T}$ lymphocytes (Kong et al. 1999). Pacifici et al. have shown that mice lacking T lymphocytes are protected from bone loss caused by ovariectomy (ovx) (i.e. estrogen deficiency), and they have also shown that ovx enhances $\mathrm{T}$ lymphocyte production of tumor necrosis factor alpha (TNF $\alpha)$, leading to increased bone loss (Kong et al. 1999, Cenci et al. 2000). Thus, T cells are strongly implicated in the estrogenic regulation of the skeleton, but it is not known whether T lymphocytes are direct estrogen target cells or if the involvement of $\mathrm{T}$ lymphocytes is indirect via estrogen signaling in other cells. The aim of this study was therefore to determine if $\mathrm{T}$ lymphocytes are direct estrogen target cells by evaluating the importance of ER $\alpha$ expression specifically in $\mathrm{T}$ lymphocytes for the estrogenic regulation of bone mass in female mice.

\section{Materials and methods}

\section{Animals}

All experimental procedures involving animals were approved by the Ethics Committee at the University of Gothenburg. The mice were housed in a standard animal facility under controlled temperature $\left(22^{\circ} \mathrm{C}\right)$ and photoperiod ( $12 \mathrm{~h}$ of light and $12 \mathrm{~h}$ of darkness) and fed phytoestrogen-free pellet diet (R70, Lactamin $\mathrm{AB}$, Sweden) and tap water ad libitum. To generate T lymphocyte-specific ER $\alpha$-inactivated mice, ER $\alpha^{\text {flox/flox }}$ mice on C57BL/6 background (Antonson et al. 2012), in which exon 3 of the ER $\alpha$ (Esr1) gene is flanked by loxP sequences, were crossed with Lck-Cre mice (Hennet et al. 1995) on C57BL/6 background to generate Lck-Cre;ER $\alpha^{\text {flox} /+}$ mice. The proximal Lck promoter has previously been used to promote $\mathrm{T}$ lymphocyte-specific gene inactivation (Pacifici 2012, Weitzmann 2017) and the promoter is turned on in the earliest thymic immigrants and in all subsequent $T$ cell lineages (Onal et al. 2012). The Lck-Cre;ERoflox/+ mice were crossed with $\mathrm{ER}^{\text {flox/flox }}$ mice to generate conditional mutants (Lck-Cre;ER $\alpha^{\text {flox/flox, }}$ hereafter referred to as Lck-ER $\alpha^{-/-}$) and corresponding littermate controls (ERoflox/flox). The total body areal bone mineral density (aBMD) was similar between Cre-positive and Cre-negative ERoflox/- mice (50.3 \pm 0.5 and $49.3 \pm 0.7$; $\mathrm{mg} / \mathrm{cm}^{2}$ ), demonstrating that the Cre-construct itself does not affect bone mass. Genotyping of the mice was performed by PCR using Cre primers P1: 5'-GTT CGC AAG AAC CTG ATG GAC A-3' and P2: 5'-CTA GAG CCT GTT TTG CAC GTT C-3' and ER $\alpha^{\text {flox/flox }}$ primers P3: 5'-GGA ATG AGA CTT GTC TAT CTT CGT-3' and P4: 5'-GAC ACA TGC AGC AGA AGG TA-3'. Gonadal intact female mice, 2-7 months of age, were used for measuring ER $\alpha$ mRNA expression in different tissues and for extraction of CD3-positive cells from thymus. Twelve-week-old female Lck-ER $\alpha^{-/}$mice and control littermates were ovariectomized (ovx) and treated with a subcutaneous slowrelease pellet (60-day-release pellet, Innovative Research of America) with $17 \beta$-estradiol (E2, $167 \mathrm{ng} /$ mouse/day) or placebo for 4 weeks or sham-operated and treated with placebo for 4 weeks. Surgery was performed under anesthesia with isoflurane (Baxter Medical AB, Kista, Sweden) and Rimadyl (Orion Pharma AB, Animal Health, Sollentuna, Sweden) was given postoperatively as an analgesic. At termination, the mice were anesthetized with Ketanest/Dexdomitor (Pfizer/Orion Pharma), bled and killed by cervical dislocation. Hypothalamus, uterus, fat depots and muscle were collected, weighed and snapfrozen. The femur and vertebrae L5 were dissected, fixed in $4 \%$ paraformaldehyde and stored for further analysis.

\section{CD3-positive cell separation in thymus}

CD3-positive cells were extracted from freshly dissected thymus with a mouse CD3e MicroBead Kit (MACS, Miltenyi Biotec) according to the manufacturer's protocol.

\section{Real-time PCR}

RNA was isolated from hypothalamus, fat, muscle and bone marrow from long bones (tibia and femur) using the RNeasy Mini Kit (Qiagen). RNA from cortical bone was isolated using TRIzol reagent (Sigma) followed by the RNeasy Mini Kit (Qiagen). Amplifications were performed using the Applied Biosystem StepOnePlus Real-Time PCR System (PE, Applied Biosystems) and Assay-onDemand primer and probe sets (PE, Applied Biosystems),

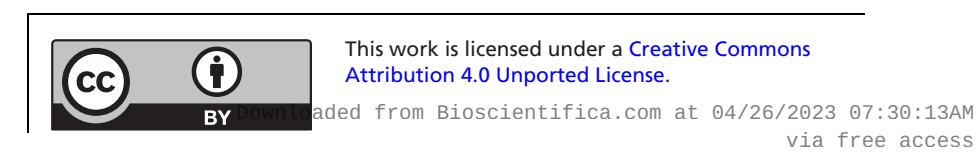


labeled with the reporter fluorescent dye FAM. Predesigned primers and probe labeled with the reporter fluorescent dye VIC, specific for 18 S ribosomal RNA, were included in the reaction as an internal standard. The assay identification number for Esr1 was Mm00433147_m1.

\section{Assessment of bone parameters}

\section{Dual-energy X-ray absorptiometry}

Analysis of total body areal bone mineral density (aBMD) and lumbar spine aBMD (vertebrae $\mathrm{L}_{2}-\mathrm{L}_{5}$ ) was performed using a Lunar PIXImus mouse densitometer (Wipro GE Healthcare).

\section{High-resolution microcomputed tomography}

High-resolution microcomputed tomography $(\mu \mathrm{CT})$ analysis was performed on the vertebrae $\mathrm{L}_{5}$ and femur using an 1172 model $\mu \mathrm{CT}$ (Bruker MicroCT, Aartselaar, Belgium) as previously described (Moverare-Skrtic et al. 2014). The vertebrae and femur were imaged with an X-ray tube voltage of $49 \mathrm{kV}$, a current of $200 \mu \mathrm{A}$ and with a $0.5 \mathrm{~mm}$ aluminum filter. The scanning angular rotation was $180^{\circ}$, and the angular increment was $0.70^{\circ}$. The voxel size was $4.49 \mathrm{~mm}$ isotropically. NRecon (version 1.6.9) was used to perform the reconstruction after the scans. In the vertebrae, the trabecular bone in the vertebral body caudal of the pedicles was selected for analysis within a conforming volume of interest (cortical bone excluded) commencing at a distance of $4.5 \mu \mathrm{m}$ caudal of the lower end of the pedicles, and extending a further longitudinal distance of $225 \mu \mathrm{m}$ in the caudal direction. In the femur, the trabecular bone proximal to the distal growth plate was selected for analyses within a conforming volume of interest (cortical bone excluded), commencing at a distance of $650 \mu \mathrm{m}$ from the growth plate and extending a further longitudinal distance of $134 \mu \mathrm{m}$ in the proximal direction. The cortical measurements in femur were performed in the mid-diaphyseal region of femur starting at a distance of $5.2 \mathrm{~mm}$ from the growth plate and extending a further longitudinal distance of $134 \mu \mathrm{m}$ in the proximal direction.

\section{Serum biomarkers}

As a marker of bone resorption, serum levels of C-terminal type I collagen fragments were assessed using an ELISA RatLaps kit (CTX-I, Immunodiagostic Systems, Copenhagen, Denmark). Serum levels of procollagen type I N propeptide (P1NP, Immunodiagostic Systems) were analyzed as a marker of bone formation.

$$
\begin{aligned}
& \text { http://joe.endocrinology-journals.org } \\
& \text { https://doi.org/10.1530/JOE-18-0183 }
\end{aligned}
$$

\section{Statistical analyses}

Values are given as mean \pm S.E.M. Statistical significance was determined using Student's $t$ test. To determine the occurrence of significant differences in the $\mathrm{E} 2$ response between Lck-ER $\alpha^{-/-}$and controls, the interaction $P$ value from a two-way ANOVA was used.

\section{Results}

\section{Generation of mice lacking ER $\alpha$ expression in T Iymphocytes}

To generate mice lacking ER $\alpha$ expression in T lymphocytes, we used the Cre-loxP system. The effectiveness of $\mathrm{ER} \alpha$ gene inactivation was demonstrated by an $84 \%$ reduction in ER $\alpha$ mRNA levels in thymic $\mathrm{T}$ lymphocytes (CD3-positive cells) in Lck-ER $\alpha^{-/-}$mice compared to controls (Fig. 1). ER $\alpha$ mRNA expression was also measured in muscle, hypothalamus, bone marrow, cortical bone and gonadal fat, and no differences were seen between Lck-ER $\alpha^{-/-}$and controls in these tissues (Fig. 1), confirming a specific impairment of ER $\alpha$ expression in T lymphocytes.

\section{Deletion of ER $\alpha$ expression in T lymphocytes does not affect bone mass or alter bone loss caused by estrogen deficiency}

Uterine weights did not differ between sham-operated Lck-ER $\alpha^{-/-}$and control mice (Table 1 ). Thymus weights were also unaffected by ER $\alpha$ inactivation in T lymphocytes (Table 1). Total body aBMD and lumbar spine aBMD, analyzed by dual-energy X-ray absorptiometry (DXA), were similar between Lck-ER $\alpha^{-/-}$and control mice (Table 1). Furthermore, analysis of trabecular bone (BV/TV;

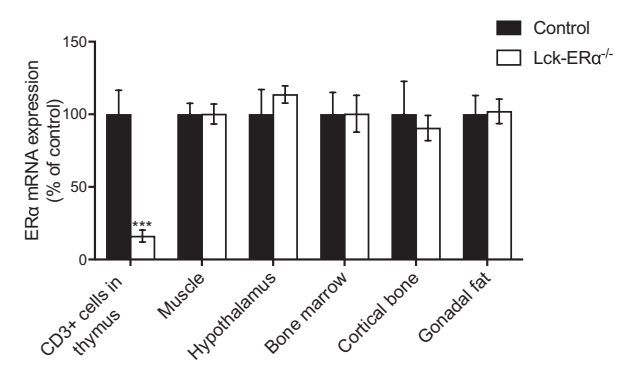

Figure 1

Specific inactivation of ER $\alpha$ mRNA expression in T lymphocytes. Two- to seven-month-old gonadal intact female mice were used to study ER $\alpha$ mRNA expression in CD3-positive cells ( $T$ lymphocytes) from thymus, muscle, hypothalamus, bone marrow, cortical bone and gonadal fat. Values are given as mean \pm S.E.m. $(n=6-13)$. *** $P<0.001$, Student's $t$ test, Lck-ER $\alpha^{-l-}$ vs controls.

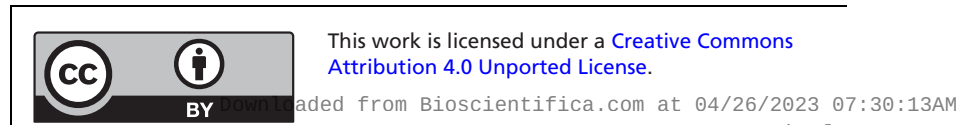


Table 1 Body and skeletal characteristics of 16-week-old sham-operated Lck-ER $\alpha^{-/-}$and control mice.

Body weight $(\mathrm{g})$
Uterus weight/bw $(\mathrm{mg} / \mathrm{g})$
Thymus weight/bw $(\mathrm{mg} / \mathrm{g})$
Total body aBMD $\left(\mathrm{mg} / \mathrm{cm}^{2}\right)$
Lumbar spine aBMD $\left(\mathrm{mg} / \mathrm{cm}^{2}\right)$
Vertebra, $\mathrm{L}_{5}$
Bone volume/total volume
(BV/TV; \%)
Trabecular number (Tb.N; $1 / \mathrm{mm})$
Trabecular thickness (Tb.Th; $\mu \mathrm{m})$
Trabecular separation $(\mathrm{Tb} . \mathrm{Sp} ; \mu \mathrm{m})$
Femur
Bone volume/total volume
(BV/TV; \%)
Trabecular number (Tb.N; $1 / \mathrm{mm})$
Trabecular thickness (Tb.Th; $\mu \mathrm{m})$
Trabecular separation $(\mathrm{Tb} . \mathrm{Sp} ; \mu \mathrm{m})$
Cortical thickness (Ct.Th; $\mu \mathrm{m})$
Endosteal circumference
(Endo. C; mm)
Periosteal circumference
(Peri. C; mm)
Serum biomarkers
P1NP (ng/mL)
CTX-I (ng/mL)

Values are given as mean \pm S.E.M. $(n=9-10)$. Student's $t$ test, Lck-ER $\alpha^{-/-}$ vs controls.

CTX-I, C-terminal type I collagen fragments; P1NP, procollagen type I N propeptide.

bone volume/total volume, Tb.N.; trabecular number, Tb.Th.; trabecular thickness and Tb.Sp.; trabecular separation) in vertebrae $\left(\mathrm{L}_{5}\right)$ revealed no significant differences between Lck-ER $\alpha^{-/-}$and control mice (Table 1). Trabecular (BV/TV, Tb.N., Tb.Th. and Tb.Sp.) and cortical (Ct.Th.; cortical thickness, Endo. C.; endosteal circumference and Peri. C.; periosteal circumference) bone parameters in femur were also similar between

Lck-ER $\alpha^{-/-}$and control mice (Table 1 and Supplementary Fig. 1, see section on supplementary data given at the end of this article). In addition, serum levels of biomarkers for bone formation (P1NP) and bone resorption (CTX-I) were similar between Lck-ER $\alpha^{-/-}$and control mice (Table 1).

Uterine weights were significantly decreased to a similar extent after ovariectomy (ovx) in control $(-83 \pm 0.9 \%, \quad P<0.001)$ and Lck-ER $\alpha^{-/} \quad(-85 \pm 0.7 \%$, $P<0.001)$ mice confirming successful ovx. Ovx resulted in a similar increase in thymus weight in control (42 $\pm 3.6 \%, \quad P<0.001)$ and Lck-ER $\alpha^{-/-} \quad(32 \pm 4.5 \%$, $P<0.001)$ mice compared to sham-operated mice. Furthermore, total body aBMD was decreased after ovx to a similar extent in control $(-4.2 \pm 1.4 \%, P<0.05)$ and Lck-ER $\alpha^{-/-}$mice $(-5.7 \pm 0.7 \% \quad P<0.001)$ as compared to sham-operated mice.

\section{ER $\alpha$ expression in T Iymphocytes is not required for a normal estrogenic response in bone}

E2 treatment increased uterine weights and decreased thymus weights to a similar extent in Lck-ER $\alpha^{-/-}$and control mice compared to vehicle-treated mice (Table 2). Skeletal analyses demonstrated a similar increase in total body aBMD and lumbar spine aBMD after estrogen treatment in Lck-ER $\alpha^{-/-}$and control mice compared to vehicle treatment (Fig. 2A and B). Estrogen treatment increased trabecular $\mathrm{BV} / \mathrm{TV}$ in vertebrae $\mathrm{L}_{5}$ to a similar extent in Lck-ER $\alpha^{-/-}$mice and controls (Fig. 3A). Furthermore, analysis of microstructural parameters in vertebral trabecular bone revealed no significant differences in the response to estrogen treatment between Lck-ER $\alpha^{-1-}$ mice and controls in regards to trabecular number (Tb.N.), trabecular thickness (Tb.Th.) and trabecular separation (Tb.Sp.) (Fig. 3B, C and D). The estrogen treatment response on trabecular bone parameters (BV/TV, Tb.N., Tb.Th. and

Table 2 The estrogen response on organ weights and trabecular bone parameters in femur are not mediated via estrogen receptor alpha $(E R \alpha)$ in T lymphocytes.

\begin{tabular}{|c|c|c|c|c|}
\hline & \multicolumn{2}{|c|}{ Control } & \multicolumn{2}{|c|}{ Lck-ER $\alpha^{-l-}$} \\
\hline & $\mathrm{Ovx}+\mathrm{P}$ & $\mathrm{Ovx}+\mathrm{E} 2$ & Ovx $+P$ & $\mathrm{Ovx}+\mathrm{E} 2$ \\
\hline Uterus weight/bw (mg/g) & $0.50 \pm 0.03$ & $8.52 \pm 0.95 * * *$ & $0.46 \pm 0.03$ & $7.12 \pm 0.75 * * *$ \\
\hline Thymus weight/bw (mg/g) & $3.45 \pm 0.10$ & $0.41 \pm 0.04 * * *$ & $3.33 \pm 0.14$ & $0.54 \pm 0.13 * * *$ \\
\hline \multicolumn{5}{|l|}{ Femur } \\
\hline Bone volume/total volume (BV/TV; \%) & $13.0 \pm 0.5$ & $55.9 \pm 1.9 * * *$ & $12.4 \pm 0.6$ & $48.8 \pm 3.3 * * *$ \\
\hline Trabecular number (Tb.N; 1/mm) & $3.2 \pm 0.1$ & $13.0 \pm 0.3 * * *$ & $3.0 \pm 0.1$ & $11.4 \pm 1.0 * * *$ \\
\hline Trabecular thickness (Tb.Th; $\mu \mathrm{m}$ ) & $40.8 \pm 0.6$ & $43.0 \pm 1.6$ & $41.3 \pm 0.8$ & $43.8 \pm 1.2$ \\
\hline Trabecular separation (Tb.Sp; $\mu \mathrm{m}$ ) & $120 \pm 1.3$ & $45.1 \pm 2.0 * * *$ & $123 \pm 0.9$ & $54.4 \pm 5.6 * * *$ \\
\hline
\end{tabular}

12-week-old Lck-ER $\alpha^{-/-}$and control mice were ovariectomized (ovx) and treated with 17 $\beta$-estradiol (E2, 167 ng/mouse/day) or placebo (P) for 4 weeks. Values are given as mean \pm S.E.M. $(n=9-10)$.

$* * * P<0.001$, Student's $t$ test, E2 vs placebo treatment.

http://joe.endocrinology-journals.org https://doi.org/10.1530/JOE-18-0183
C 2018 The authors Published by Bioscientifica Ltd. Printed in Great Britain

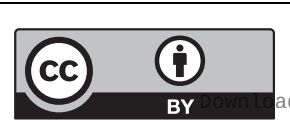

This work is licensed under a Creative Commons Attribution 4.0 Unported License. 
A
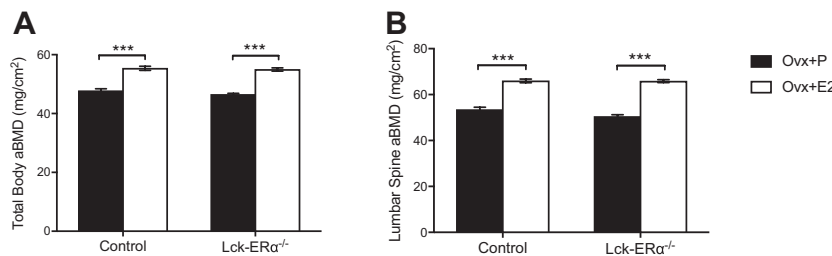

Figure 2

The estrogen response in total body areal bone mineral density is not mediated via estrogen receptor alpha $(E R \alpha)$ in T lymphocytes. Twelve-

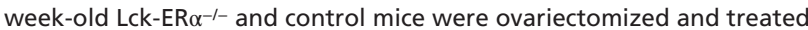
with $17 \beta$-estradiol (E2, $167 \mathrm{ng} /$ mouse/day) or placebo (P) for 4 weeks. Total body areal bone mineral density (aBMD) (A) and lumbar spine aBMD (B) were measured by DXA. Values are given as mean \pm S.E.M. $(n=9-10) . * * * P<0.001$, Student's $t$ test, E2 vs placebo treatment.

Tb.Sp.) in the appendicular skeleton, analyzed in femur, was also similar in Lck-ER $\alpha^{-/-}$mice and controls (Table 2 and Supplementary Fig. 2). Cortical bone parameters were determined in the mid-diaphyseal region of femur and estrogen resulted in a similar increase in cortical thickness (Ct.Th.) and a similar decrease in endosteal circumference (Endo. C.) in Lck-ER $\alpha^{-/-}$mice and controls (Fig. 4A, B and Supplementary Fig. 2).

\section{Discussion}

It is well established that estrogen has positive effects on bone, but also that it is not suitable as an anti-resorptive osteoporosis treatment due to adverse side effects (Rossouw et al. 2002, Barrett-Connor et al. 2005, Khosla 2010, Marjoribanks et al. 2017). To be able to develop new estrogen-like drugs against bone loss, which lack negative estrogenic effects, it is important to increase the knowledge regarding mechanisms behind the effects of estrogen on bone. We have recently showed that ER $\alpha$ expression in hematopoietic cells is required for a normal estrogenic treatment response in bone (Henning et al. 2014), but it was not established, which cell type of hematopoietic origin that was involved in these effects. It is demonstrated that ER $\alpha$ expression in osteoclasts, derived from the hematopoietic lineage, is involved in the regulation of trabecular bone (Nakamura et al. 2007, Martin-Millan et al. 2010). However, several other cell types of hematopoietic origin are also implicated to be involved in estrogenic regulation of bone mass, including T lymphocytes (Weitzmann \& Pacifici 2007).

Estrogen deficiency leads to increased thymic outflow of naïve T lymphocytes and increased activation of T cells (Pacifici 2012, Weitzmann 2017). These events lead to enhanced production of TNFo, which results in increased

$$
\text { http://joe.endocrinology-journals.org }
$$
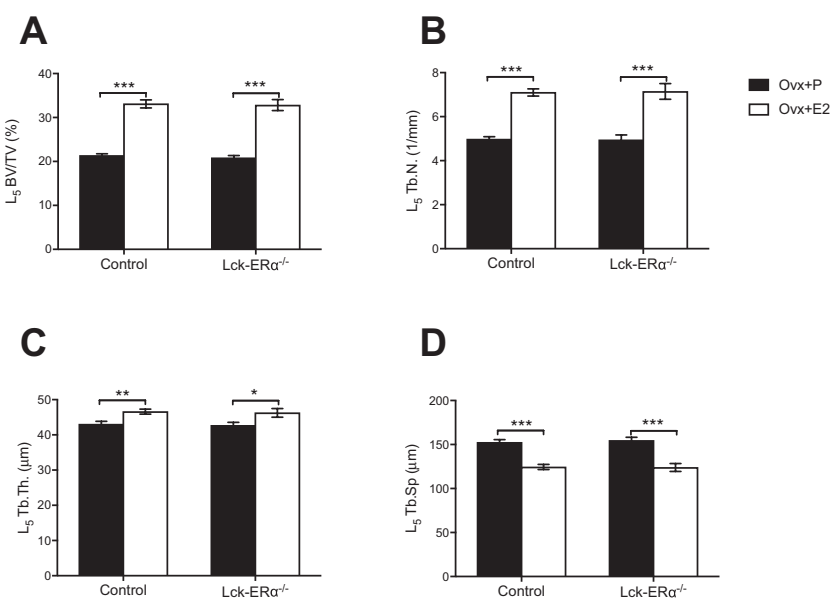

\section{Figure 3}

The estrogen response in trabecular bone is not mediated via estrogen receptor alpha (ER $\alpha)$ in T lymphocytes. Twelve-week-old Lck-ER $\alpha^{-1-}$ and control mice were ovariectomized and treated with $17 \beta$-estradiol (E2, $167 \mathrm{ng} / \mathrm{mouse} / \mathrm{day}$ ) or placebo (P) for 4 weeks. Bone volume per tissue volume (BV/TV) (A), trabecular number (Tb.N.) (B), trabecular thickness (Tb.Th.) (C) and trabecular separation (Tb.Sp.) (D) were analyzed in vertebrae $\mathrm{L}_{5}$ using high-resolution microcomputed tomography $(\mu \mathrm{CT})$. Values are given as mean \pm s.E.M. $(n=9-10) .{ }^{*} P<0.05, * * P<0.01$, $* * * P<0.001$, Student's $t$ test, E2 vs placebo treatment.

differentiation and activation of osteoclasts (Cenci et al. 2000) and are suggested to be part of the mechanism behind bone loss caused by estrogen deficiency. Thus, presence of estrogen suppresses T lymphocyte-associated deleterious effects on the skeleton. However, it is not established whether these effects are direct, via effects on estrogen signaling in $\mathrm{T}$ lymphocytes, or indirect, via estrogenic effects on other cell types, and this is addressed in the present study. If one hypothesizes that the role of T lymphocytes in estrogen deficiency-induced bone loss involves direct alteration of ER $\alpha$ signaling in $\mathrm{T}$ lymphocytes, inactivation of ER $\alpha$ expression in $\mathrm{T}$ lymphocytes would lead to a decreased estrogenic
A

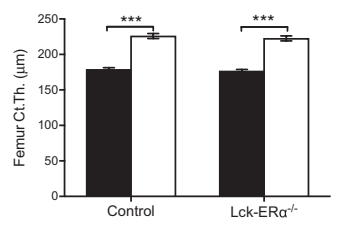

B

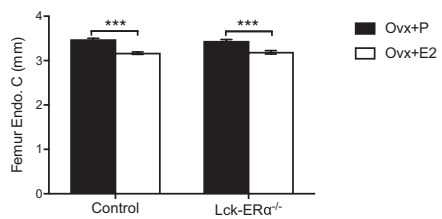

Figure 4

The estrogen response in cortical bone is not mediated via estrogen receptor alpha (ER $\alpha)$ in T lymphocytes. Twelve-week-old Lck-ER $\alpha^{-1-}$ and control mice were ovariectomized and treated with 17 $\beta$-estradiol (E2, $167 \mathrm{ng} / \mathrm{mouse} / \mathrm{day}$ ) or placebo (P) for 4 weeks. Cortical thickness (Ct.Th.) (A) and endosteal circumference (Endo C.) (B) were analyzed in femur using high-resolution microcomputed tomography $(\mu \mathrm{CT})$. Values are given as mean \pm S.E.M. $(n=9-10) .{ }^{* * *} P<0.001$, Student's $t$ test, E2 vs placebo treatment. 
suppression of $\mathrm{T}$ lymphocyte-associated skeletal effects and thereby decreased bone mass.

To investigate this, we have generated mice with impaired ERo expression specifically in T lymphocytes and studied the effects on bone mass and also how the skeleton responds to estrogen deficiency and estrogen treatment.

Analysis of the skeleton in mice lacking ERo expression in T lymphocytes showed no significant difference in total body aBMD compared to littermate controls. Trabecular bone parameters in both femur and vertebrae were also unchanged by $\mathrm{T}$ lymphocyte-specific inactivation of $\mathrm{ER} \alpha$, as was cortical bone parameters measurements in the mid-diaphyseal part of femur. In addition, serum levels of biomarkers for bone formation and bone resorption were unaffected by $\mathrm{T}$ lymphocyte-specific inactivation of $\mathrm{ER} \alpha$. These data suggest that the ERo in T lymphocytes is dispensable for normal regulation of bone mass in female mice.

As expected, estrogen deficiency, induced by ovariectomy, led to decreased total body aBMD in control mice. Ovariectomy led to a similar decrease in total body aBMD in mice lacking ER $\alpha$ expression in T lymphocytes, suggesting that ER $\alpha$ signaling in $T$ lymphocytes is dispensable for bone loss caused by estrogen deficiency. These results support the previous study by Lee et al. showing that $\mathrm{T}$ lymphocyte-deficient mice have a normal ovariectomy-induced bone loss (Lee et al. 2006). B lymphocytes have also been implicated in bone loss caused by estrogen deficiency, and deletion of RANKL expression in B lymphocytes blunted bone loss in ovariectomized mice (Onal et al. 2012). However, it was recently shown that this was not dependent on ER $\alpha$ expression in B lymphocytes since mice with a specific deletion of ER $\alpha$ in B lymphocytes experienced a similar bone loss as normal controls (Fujiwara et al. 2016). Thus, ER $\alpha$ signaling in both $\mathrm{T}$ and $\mathrm{B}$ lymphocytes is dispensable for bone loss caused by estrogen deficiency.

As previously shown by us and others (Lindberg et al. 2002, Sims et al. 2003, Borjesson et al. 2011), E2 treatment increased total body aBMD and both trabecular and cortical bone parameters in ovariectomized control mice. Interestingly, and in contrast to the requirement of ER $\alpha$ expression in T lymphocytes for the ameliorating effects of pharmacological E2 treatment on experimental autoimmune encephalomyelitis (Lelu et al. 2011), the skeletal response to estrogen treatment in mice lacking $\mathrm{ER} \alpha$ expression in T lymphocytes did not differ from the response in control mice. Thus, the beneficial effects of E2 treatment on bone does not require direct interaction of E2 with ERo in T lymphocytes.
Osteoclasts, which are of hematopoietic origin, have been shown to respond to estrogen directly via ER $\alpha$, and it is demonstrated that ERo expression in osteoclasts is important for the regulation of trabecular bone in females (Nakamura etal. 2007, Martin-Millan etal. 2010). Regarding cortical bone, the available evidence suggests that the protective effects of estrogen is mediated mainly via direct actions on mesenchymal cells (Almeida et al. 2013, 2017, Manolagas et al. 2013, Ucer et al. 2016). However, our previous finding (Henning et al. 2014) suggests that part of the estrogenic protection of cortical bone is mediated via direct estrogen action in hematopoietic cells. Since inactivation of ER $\alpha$ in osteoclasts has been suggested not to affect cortical bone in females, further studies are needed to determine which other hematopoietic cell type is involved.

Estrogen treatment is known to induce thymic atrophy and global inactivation of ER $\alpha$ results in impaired thymic atrophy after estrogen treatment (Lindberg et al. 2002), demonstrating that $\mathrm{ER} \alpha$, at least partly, is involved in mediating this atrophic effect. The effect of estrogen treatment on thymus weight in our study was unaffected by inactivation of ER $\alpha$ in T lymphocytes, demonstrating that the ERo-mediated effect on thymic atrophy is independent of $E R \alpha$ signaling in T lymphocytes. Thus, the atrophic effect of estrogen is most probably mediated via other cells in the thymus and epithelial cells in the thymus stroma have previously been implicated (Staples et al. 1999).

Taken together, these data demonstrate that ER $\alpha$ expression in $\mathrm{T}$ lymphocytes is not required for a normal response to estrogen treatment neither in trabecular nor in cortical bone in ovariectomized female mice. Thus, our data suggest that $\mathrm{T}$ lymphocytes are not a direct target cell for the protective effects of estrogen on bone and implicate other cell types as primary estrogen-responsive cells mediating the positive estrogenic effects on bone. In conclusion, our data suggest that ER $\alpha$ expression in $\mathrm{T}$ lymphocytes is dispensable for ovariectomy-induced bone loss and response to estrogen treatment in bone after ovariectomy.

\section{Supplementary data}

This is linked to the online version of the paper at https://doi.org/10.1530/ JOE-18-0183.

Declaration of interest

The authors declare that there is no conflict of interest that could be perceived as prejudicing the impartiality of the research reported.

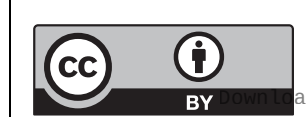

This work is licensed under a Creative Commons Attribution 4.0 Unported License. 


\section{Funding}

The Swedish Research Council (grant number 2017-01286); the Swedish Foundation for Strategic Research; the ALF/LUA research grant from the Sahlgrenska University Hospital (grant number ALFGBG-721581); the Gustaf V 80-year fund (grant number FAI-2016-0286); the Swedish Rheumatism Association (grant number R-754891); the Lundberg Foundation (grant number 2017-0076); the Torsten and Ragnar Söderberg's Foundations (grant number M133/12); the Knut and Alice Wallenberg Foundation (grant number KAW 2015.0317) and the Novo Nordisk Foundation (grant number NNF170C0026844). J A G is thankful to the Robert A. Welch Foundation for a grant (E-0004).

\section{Author contribution statement}

$\mathrm{K} \mathrm{L} \mathrm{G}, \mathrm{CO}$ and $\mathrm{M} \mathrm{K} \mathrm{L}$ conducted the study design. $\mathrm{KL} \mathrm{G}, \mathrm{M} \mathrm{KL}, \mathrm{K} \mathrm{N}, \mathrm{A} A$, $\mathrm{H} \mathrm{F}, \mathrm{V} \mathrm{L}, \mathrm{PH}, \mathrm{J}$ W, U I, S H W, S M S and $\mathrm{K} \mathrm{S}$ were responsible for acquisition of data and $K L G, M K L, J \AA G$ and $C O$ performed the analysis and interpretation of data. M K L, K L G and C O wrote the main manuscript text and KL G and M K L prepared the figures. All authors reviewed the manuscript.

\section{Acknowledgements}

The authors thank Charlotta Uggla, Biljana Aleksic and Anette Hansevi for excellent technical assistance.

\section{References}

Almeida M, Iyer S, Martin-Millan M, Bartell SM, Han L, Ambrogini E, Onal M, Xiong J, Weinstein RS, Jilka RL, et al. 2013 Estrogen receptoralpha signaling in osteoblast progenitors stimulates cortical bone accrual. Journal of Clinical Investigation 123 394-404. (https://doi. org/10.1172/JCI65910)

Almeida M, Laurent MR, Dubois V, Claessens F, O'Brien CA, Bouillon R, Vanderschueren D \& Manolagas SC 2017 Estrogens and androgens in skeletal physiology and pathophysiology. Physiological Reviews 97 135-187. (https://doi.org/10.1152/physrev.00033.2015)

Antonson P, Omoto Y, Humire P \& Gustafsson JA 2012 Generation of ERalpha-floxed and knockout mice using the Cre/LoxP system. Biochemical and Biophysical Research Communications 424 710-716. (https://doi.org/10.1016/j.bbrc.2012.07.016)

Barrett-Connor E, Grady D \& Stefanick ML 2005 The rise and fall of menopausal hormone therapy. Annual Review of Public Health 26 115-140. (https://doi.org/10.1146/annurev. publhealth.26.021304.144637)

Borjesson AE, Windahl SH, Lagerquist MK, Engdahl C, Frenkel B, Moverare-Skrtic S, Sjogren K, Kindblom JM, Stubelius A, Islander U, et al. 2011 Roles of transactivating functions 1 and 2 of estrogen receptor-alpha in bone. PNAS 108 6288-6293. (https://doi. org/10.1073/pnas.1100454108)

Cenci S, Weitzmann MN, Roggia C, Namba N, Novack D, Woodring J \& Pacifici R 2000 Estrogen deficiency induces bone loss by enhancing T-cell production of TNF-alpha. Journal of Clinical Investigation $\mathbf{1 0 6}$ 1229-1237. (https://doi.org/10.1172/JCI11066)

Ettinger B 1988 Prevention of osteoporosis: treatment of estradiol deficiency. Obstetrics and Gynecology 72 12s-17s.

Fujiwara Y, Piemontese M, Liu Y, Thostenson JD, Xiong J \& O’Brien CA 2016 RANKL (Receptor Activator of NFkappaB Ligand) produced by osteocytes is required for the increase in B cells and bone loss caused by estrogen deficiency in mice. Journal of Biological Chemistry 291 24838-24850. (https://doi.org/10.1074/jbc.M116.742452)

Hennet T, Hagen FK, Tabak LA \& Marth JD 1995 T-cell-specific deletion of a polypeptide $\mathrm{N}$-acetylgalactosaminyl-transferase gene by site-directed recombination. PNAS 92 12070-12074. (https://doi.org/10.1073/ pnas.92.26.12070)

Henning P, Ohlsson C, Engdahl C, Farman H, Windahl SH, Carlsten H \& Lagerquist MK 2014 The effect of estrogen on bone requires ERalpha in nonhematopoietic cells but is enhanced by ERalpha in hematopoietic cells. American Journal of Physiology: Endocrinology and Metabolism 307 E589-E595. (https://doi.org/10.1152/ ajpendo.00255.2014)

Khosla S 2010 Update on estrogens and the skeleton. Journal of Clinical Endocrinology and Metabolism 95 3569-3577. (https://doi.org/10.1210/ jc.2010-0856)

Kong YY, Feige U, Sarosi I, Bolon B, Tafuri A, Morony S, Capparelli C, Li J, Elliott R, McCabe S, et al. 1999 Activated T cells regulate bone loss and joint destruction in adjuvant arthritis through osteoprotegerin ligand. Nature 402 304-309. (https://doi.org/10.1038/46303)

Lee SK, Kadono Y, Okada F, Jacquin C, Koczon-Jaremko B, Gronowicz G, Adams DJ, Aguila HL, Choi Y \& Lorenzo JA 2006 T lymphocytedeficient mice lose trabecular bone mass with ovariectomy. Journal of Bone and Mineral Research 21 1704-1712. (https://doi.org/10.1359/ jbmr.060726)

Lelu K, Laffont S, Delpy L, Paulet PE, Perinat T, Tschanz SA, Pelletier L, Engelhardt B \& Guery JC 2011 Estrogen receptor alpha signaling in T lymphocytes is required for estradiol-mediated inhibition of Th1 and Th17 cell differentiation and protection against experimental autoimmune encephalomyelitis. Journal of Immunology $\mathbf{1 8 7}$ 2386-2393. (https://doi.org/10.4049/jimmunol.1101578)

Lindberg MK, Weihua Z, Andersson N, Moverare S, Gao H, Vidal O, Erlandsson M, Windahl S, Andersson G, Lubahn DB, et al. 2002 Estrogen receptor specificity for the effects of estrogen in ovariectomized mice. Journal of Endocrinology 174 167-178. (https:// doi.org/10.1677/joe.0.1740167)

Maatta JA, Buki KG, Gu G, Alanne MH, Vaaraniemi J, Liljenback H, Poutanen M, Harkonen P \& Vaananen K 2013 Inactivation of estrogen receptor alpha in bone-forming cells induces bone loss in female mice. FASEB Journal 27 478-488. (https://doi.org/10.1096/ fj.12-213587)

Manolagas SC, O'Brien CA \& Almeida M 2013 The role of estrogen and androgen receptors in bone health and disease. Nature Reviews Endocrinology 9 699-712. (https://doi.org/10.1038/nrendo.2013.179)

Marjoribanks J, Farquhar C, Roberts H, Lethaby A \& Lee J 2017 Long-term hormone therapy for perimenopausal and postmenopausal women. Cochrane Database of Systematic Reviews 1 CD004143. (https://doi. org/10.1002/14651858.CD004143.pub5)

Martin-Millan M, Almeida M, Ambrogini E, Han L, Zhao H, Weinstein RS, Jilka RL, O'Brien CA \& Manolagas SC 2010 The estrogen receptoralpha in osteoclasts mediates the protective effects of estrogens on cancellous but not cortical bone. Molecular Endocrinology 24 323-334. (https://doi.org/10.1210/me.2009-0354)

Melville KM, Kelly NH, Khan SA, Schimenti JC, Ross FP, Main RP \& van der Meulen MC 2014 Female mice lacking estrogen receptor-alpha in osteoblasts have compromised bone mass and strength. Journal of Bone and Mineral Research 29 370-379. (https://doi.org/10.1002/ jbmr.2082)

Moverare-Skrtic S, Henning P, Liu X, Nagano K, Saito H, Borjesson AE, Sjogren K, Windahl SH, Farman H, Kindlund B, et al. 2014 Osteoblastderived WNT16 represses osteoclastogenesis and prevents cortical bone fragility fractures. Nature Medicine 20 1279-1288. (https://doi. org/10.1038/nm.3654)

Nakamura T, Imai Y, Matsumoto T, Sato S, Takeuchi K, Igarashi K, Harada Y, Azuma Y, Krust A, Yamamoto Y, et al. 2007 Estrogen prevents bone loss via estrogen receptor alpha and induction of Fas (c) 2018 The authors Published by Bioscientifica Ltd. Printed in Great Britain

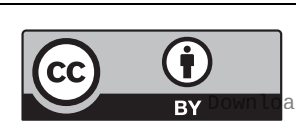

This work is licensed under a Creative Common Attribution 4.0 Unported License.

ated from Bioscientifica com at 04/26/2023 07:30:13AM 
ligand in osteoclasts. Cell 130 811-823. (https://doi.org/10.1016/j. cell.2007.07.025)

Onal M, Xiong J, Chen X, Thostenson JD, Almeida M, Manolagas SC \& O'Brien CA 2012 Receptor activator of nuclear factor kappaB ligand (RANKL) protein expression by B lymphocytes contributes to ovariectomy-induced bone loss. Journal of Biological Chemistry 287 29851-29860. (https://doi.org/10.1074/jbc.M112.377945)

Pacifici R 2012 Role of T cells in ovariectomy induced bone loss revisited. Journal of Bone and Mineral Research 27 231-239. (https:// doi.org/10.1002/jbmr.1500)

Rossouw JE, Anderson GL, Prentice RL, LaCroix AZ, Kooperberg C, Stefanick ML, Jackson RD, Beresford SA, Howard BV, Johnson KC, et al. 2002 Risks and benefits of estrogen plus progestin in healthy postmenopausal women: principal results From the Women's Health Initiative randomized controlled trial. JAMA 288 321-333. (https:// doi.org/10.1001/jama.288.3.321)

Sims NA, Clement-Lacroix P, Minet D, Fraslon-Vanhulle C, GaillardKelly M, Resche-Rigon M \& Baron R 2003 A functional androgen receptor is not sufficient to allow estradiol to protect bone after gonadectomy in estradiol receptor-deficient mice. Journal of Clinical Investigation 111 1319-1327. (https://doi.org/10.1172/ JCI200317246)
Staples JE, Gasiewicz TA, Fiore NC, Lubahn DB, Korach KS \& Silverstone AE 1999 Estrogen receptor alpha is necessary in thymic development and estradiol-induced thymic alterations. Journal of Immunology 163 4168-4174.

Ucer S, Iyer S, Kim HN, Han L, Rutlen C, Allison K, Thostenson JD, de Cabo R, Jilka RL, O'Brien C, et al. 2016 The effects of aging and sex steroid deficiency on the murine skeleton are independent and mechanistically distinct. Journal of Bone and Mineral Research 32 560-574. (https://doi.org/10.1002/jbmr.3014)

Walker VR \& Korach KS 2004 Estrogen receptor knockout mice as a model for endocrine research. ILAR Journal 45 455-461. (https://doi. org/10.1093/ilar.45.4.455)

Weitzmann MN 2017 Bone and the immune system. Toxicologic Pathology 45 911-924. (https://doi.org/10.1177/0192623317735316)

Weitzmann MN \& Pacifici R 2007 T cells: unexpected players in the bone loss induced by estrogen deficiency and in basal bone homeostasis. Annals of the New York Academy of Sciences 1116 360-375. (https://doi. org/10.1172/JCI65910)

Windahl SH, Vidal O, Andersson G, Gustafsson JA \& Ohlsson C 1999 Increased cortical bone mineral content but unchanged trabecular bone mineral density in female ERbeta(-/-) mice. Journal of Clinical Investigation 104 895-901. (https://doi.org/10.1172/JCI6730)

Received in final form 15 May 2018

Accepted 30 May 2018

Accepted Preprint published online 30 May 2018 http://joe.endocrinology-journals.org https://doi.org/10.1530/JOE-18-0183
(C) 2018 The authors Published by Bioscientifica Ltd. Printed in Great Britain
This work is licensed under a Creative Commons Attribution 4.0 Unported License.

ded from Bioscientifica.com at 04/26/2023 07:30:13AM 